УДК 547.944.945:581.17

\title{
ОПРЕДЕЛЕНИЕ СОДЕРЖАНИЯ ВИНКАМИНА И АЙМАЛИЦИНА В ИНТРОДУЦИРОВАННОМ БАРВИНКЕ МАЛОМ МЕТОДОМ ВЭЖХ-МС
}

\author{
() О.В. Молчан ${ }^{* 1}$, С.А. Фатыхова ${ }^{2}$, П.С. Шабуня ${ }^{2}$, В.М. Юрин ${ }^{3}$ \\ ${ }^{1}$ Институт экспериментальной ботаники им. В.Ф. Купревича НАН Беларуси, \\ ул. Академическая, 27, Минск, 200072 (Республика Беларусь), \\ e-mail:olga_molchan@mail.ru \\ ${ }^{2}$ Институт биоорганической химии НАН Беларуси, ул. Купревича, 2, Минск, \\ 220041 (Республика Беларусь) \\ ${ }^{3}$ Белорусский государственный университет, пр. Независимости, 4, Минск, \\ 200030 (Республика Беларусь)
}

С использованием метода ВЭЖХ-МС проведено определение содержания суммы терпеновых индольных алкалоидов, а также винкамина и аймалицина в растениях барвинка малого (лат. Vinca minor L., сем. Аросуnaceae), интродуцированного на территории Беларуси в условиях умеренного континентального климата. Показано, что содержание суммы алкалоидов и винкамина в траве и листьях интродуцированного барвинка сравнимо с содержанием в растениях, произрастающих в более южных регионах. В экстрактах также был идентифицирован фармакологически ценный гипотензивный алкалоид аймалицин. Изучено распределение винкамина и аймалицина в различных органах растения в период цветения. Установлено, что для эффективной экстракции суммы индольных алкалоидов из исследуемого сырья целесообразно использовать водные растворы этилового спирта (не менее 50\%) и уксусной кислоты (1-5\%). Максимальный выход винкамина и аймалицина установлен при использовании в качестве экстрагенов $96 \%$ этанола и $5 \%$ уксусной кислоты.

Ключевые слова: барвинок малый (Vinca minor L.), терпеновые индольные алкалоиды (ТИА), винкамин, аймалицин.

\section{Введение}

Барвинок малый является дикорастущим растением в странах Центральной и Южной Европы, а также в Молдавии, Крыму и на Кавказе $[1,2]$. Для него характерен европейско-средиземноморский тип ареала. Фармакологическая ценность Vinca minor L. (сем. Аросуnaceae) обусловлена высоким содержанием в надземной части растения терпеновых индольных алкалоидов (ТИА), основным из которых является винкамин [1]. Содержание суммы алкалоидов в сырье $V$. minor составляет $0,45-0,85 \%$, винкамина - 0,02$0,1 \%$ в пересчете на сухую массу. Заготавливаемые в качестве сырья побеги (трава) барвинка используются как для выделения суммы алкалоидов, так и для получения чистого винкамина [1]. Препараты винкамина улучшают мозговое кровообращение, оказывают сосудорасширяющее и стимулирующее метаболизм центральной нервной системы действие [3]. Среди показаний к применению винкамина - спазм сосудов головного мозга и нарушения мозгового кровообращения после ишемического инсульта, при черепномозговой травме, атеросклерозе, посткоммационной черепно-мозговой гипертензии и т.д. [3]. Лекарственные препараты, содержащие сумму ТИА V. minor, оказывают сосудорасширяющее (преимущественно на сосуды головного мозга), гипотензивное и седативное действие, их применяют при неврогенной тахикар-

Молчан Ольга Викторовна - заведующая лабораторией водного обмена и фотосинтеза, кандидат биологических наук, доцент, e-mail: olga_molchan@mail.ru Фатьххва Светлана Анатольевна - научный сотрудник Шабуня Полина Станиславовна - старший научный сотрудник, кандидат биологических наук Юрин Владимир Михайлович - профессор биологического факультета, доктор биологических наук дии, в отоларингологической и офтальмологической практике, при депрессивных состояниях и т. д. [3]. В народной медицине некоторых стран настои и отвары травы барвинка малого также используют как противовоспалительное средство для лечения целого ряда заболеваний [1].

\footnotetext{
* Автор, с которым следует вести переписку.
} 
На территории Беларуси это растение является интродуцентом и в качестве лекарственного сырья не заготавливается. При этом анализ современного распространения и фитоценотических особенностей барвинка свидетельствует о том, что ареал вида значительно расширился в северном и восточном направлениях [4, 5]. В последние десятилетия из мест первичной интродукции барвинок распространился в полуестественные (парковые) фитоценозы. Отмечаются также случаи широкой натурализации вида в естественных лесных фитоценозах с образованием популяций высокой плотности и длительного доминирования в надпочвенном покрове [4, 5]. Таким образом, представляется возможным промышленное культивирование и заготовка сырья барвинка малого в условиях характерного для Беларуси умеренного континентального климата. При этом для оценки качества растительного сырья барвинка прежде всего необходимо изучение качественного и количественного составов ТИА в растениях, так как содержание фармакологически ценных вторичных метаболитов, как правило, зависит от агроклиматических условий произрастания.

Цель настоящей работы - определение содержания суммы и индивидуальных фармакологически ценных ТИА, в том числе основного алкалоида барвинка - винкамина - в растениях V. minor, произрастающих в условиях умеренного континентального климата Беларуси.

\section{Экспериментальная часть}

Материалом для исследования служили вертикальные побеги (трава), листья вегетативных побегов, цветки и корни барвинка малого, собранные в период цветения на территории Минского района Республики Беларусь. Заготовку и исследование сырья проводили в течение 5 лет (май-июнь 2008-2014 гг.) Воздушно-сухое сырье получали высушиванием при $40{ }^{\circ} \mathrm{C}$ и измельчали. Для анализа использовали фракции размером до 1 мм. Влажность сухого сырья не превышала 9\%.

Для первичной экстракции ТИА из сухого сырья существуют различные методы [6-10]. В данной работе мы использовали наиболее распространенные: экстракцию водными растворами этилового спирта $[6,7]$ и кислот $[8,9]$ с очисткой от сопутствующих соединений, последующим переводом экстрагированных алкалоидов в основное состояние, подщелачиванием экстракта и выделением ТИА органическим растворителем - хлороформом. Исследуемое сырье трехкратно в течение 24 ч экстрагировали водными растворами этанола, уксусной или соляной кислот при комнатной температуре [6]. Полученные экстракты объединяли, концентрировали, разбавляли бидистиллированной водой, при необходимости подкисляли $3 \%$ $\mathrm{HCl}$ и трижды очищали экстракт гексаном. Гексановую фракцию отбрасывали, а водный экстракт охлаждали до $10^{\circ} \mathrm{C}$, доводили значение $\mathrm{pH}$ до 10 раствором аммиака и трижды экстрагировали ТИА хлороформом. Полученные экстракты промывали водой, объединяли и упаривали. Осадок взвешивали для определения суммы ТИА либо растворяли в метаноле и использовали для ВЭЖХ-МС анализа.

Содержание винкамина и аймалицина в экстрактах определяли методом ВЭЖХ в сочетании с тандемной масс-спектрометрией (MC/MC). Растворы стандартов аймалицина (1 мг/мл) и винкамина (1 мг/мл) готовили путем растворения чистых веществ в метаноле. Стандартные растворы и образцы экстрактов хранили при $-20{ }^{\circ} \mathrm{C}$. Перед анализом образцы размораживали при комнатной температуре. Растворы для построения калибровочных кривых готовили в день эксперимента в диапазоне концентраций аймалицина и винкамина от 10 до 5000 нг/мл путем соответствующих разбавлений метанолом. Разделение компонентов проб проводили на колонке Zorbax Extend C18 (3,0 × 100 мм; 1,8 мкм) при температуре $+40{ }^{\circ} \mathrm{C}$ с использованием жидкостного хроматографа Agilent 1200. Подвижная фаза состояла из двух растворителей: $A-8$ мМ раствор ацетата аммония в деионизованной воде и $B-100 \%$ ацетонитрил. Был применен градиентный режим элюирования от 20 до $80 \%$ фазы $B$ за 20 мин при скорости потока 0,4 мл/мин. Объем инжекции 2 мкл. С выхода хроматографа образец подавался на вход тандемного масс-спектрометра Agilent 6410 Triple Quad (тройной квадруполь). В качестве интерфейса ионизации был использован электроспрей в режиме генерации положительных ионов. Для количественного анализа аймалицина и винкамина использовали режим мониторинга заданных реакций (Multi Reaction Monitoring - MRM) при следующих переходах: для аймалицина $\mathrm{m} / \mathrm{z} 353 \rightarrow 144$ и $353 \rightarrow 127$; для винкамина $\mathrm{m} / \mathrm{z} 355 \rightarrow 337$ и $355 \rightarrow 144$. Параметры работы детектора: температура осушающего газа $+350{ }^{\circ} \mathrm{C}$; скорость потока осушающего газа - 10 л/мин; давление на распылителе - 30 рsi; напряжение на капилляре - 4000 В; напряжение на фрагменторе - 132 В. MRM-переходы и энергия в ячейке соударений указаны в таблице 1. 
Таблица 1. MRM-переходы и значения энергии в ячейке соударений

\begin{tabular}{l|c|c}
\hline \multicolumn{1}{c|}{ Название вещества } & МRM- переход & Энергия в ячейке соударений, вольт \\
\hline \multirow{2}{*}{ Аймалицин } & $353 \rightarrow 144$ & 18 \\
& $353 \rightarrow 127$ & 38 \\
\multirow{2}{*}{ Винкамин } & $355 \rightarrow 337$ & 26 \\
& $355 \rightarrow 144$ & 60 \\
\hline
\end{tabular}

\section{Обсуждение результатов}

Следует отметить, что большая часть исследований ТИА барвинка малого проводились в 50-70-х гг. прошлого века. В большинстве случаев для идентификации качественного состава исследуемых алкалоидов использовали тонкослойную и ионообменную хроматографии. Только в единичных работах, опубликованных в последние 20 лет, разделение и идентификацию ТИА барвинка малого проводили с использованием ВЭЖХ с УФ-детектированием [6-10]. В то же время применение современных методов позволяет, с одной стороны, более точно идентифицировать исследуемые соединения, с другой - проводить анализ и стандартизацию лекарственного растительного сырья на качественно новом уровне. Тандемная массспектрометрия в MRM-режиме предоставляет возможность проанализировать вещества на низких уровнях концентраций в многокомпонентных образцах растительных экстрактов. Предварительное разделение компонентов пробы на современной мелкозернистой хроматографической колонке, а также использование стандартов искомых веществ позволяют точно идентифицировать и количественно определять их содержание в экстрактах на фоне большого количества близкородственных соединений. Высокая чувствительность масс-спектрометрического детектирования по сравнению с УФ-детектированием дает возможность определить вещества в очень низких концентрациях, на уровне нг/мл.

На представленных хроматограммах (рис. 1А, 1Б) стандартов винкамина и одного из экстрактов хорошо видно, что использование детектирования в режиме MRM позволяет точно идентифицировать винкамин, несмотря на присутствие большого количества пиков, соответствующих, скорее всего, неидентифицированным близкородственным соединениям. Интересно было также обнаружить в исследуемом экстракте аймалицин (рис. 1) - терпеновый индольный алкалоид с гипотензивной активностью, ранее идентифицируемый в растениях катарантуса розового и раувольфии змеиной [11]. Предполагается, что именно чувствительность используемого метода разделения и идентификации веществ позволила идентифицировать алкалоид с крайне низким уровнем содержания.

Для определения содержания винкамина и аймалицина в интродуцированных растениях барвинка малого прежде всего была определена сумма алкалоидов, экстрагируемых из травы водными растворами этилового спирта и кислот - соляной и уксусной. Как видно из данных, представленных на рисунке 2, наибольший выход алкалоидов (0,52-0,58\% в пересчете на сухую массу) из травы отмечен при экстракции водными растворами этилового спирта. Увеличение концентрации этанола сопровождалось ростом содержания алкалоидов в экстрактах. Некоторыми авторами ранее было показано, что для извлечения алкалоидов, например, из листьев маклейи сердцевидной, наиболее эффективно использование хлористоводородной и уксусной кислот в высоких концентрациях [11]. Однако, как видно на рисунке 2, экстракция водными растворами кислот ТИА барвинка малого была менее эффективной, даже при повышении их концентраций. Наименьшим был выход ТИА из травы V. minor в экстракты на основе соляной кислоты и составлял в среднем $0,12 \%$. При экстрагировании раствором уксусной кислоты выход алкалоидов из травы составлял $0,35-0,42 \%$. Таким образом, очевидно, что из травы барвинка малого, растущего в условиях умеренного континентального климата Беларуси, можно выделить значительное количество ТИА. При этом полученные величины содержания суммы алкалоидов сходны с содержанием ТИА в траве Vinca minor, заготавливаемой в качестве лекарственного растительного сырья в странах Центральной и Южной Европы $[1,2,5]$.

Максимальным было содержание винкамина в спиртовых экстрактах и составляло 500-600 мкг/г, или $0,05-0,06 \%$ в пересчете на сухую массу (рис. 3А). Данная величина сопоставима с содержанием винкамина в траве барвинка малого, произрастающего в более южных регионах [1]. При экстрагировании раствором уксусной кислоты выход винкамина из травы снижался до 350-400 мкг/г. Экстракция соляной кислотой оказалась наименее эффективной. 

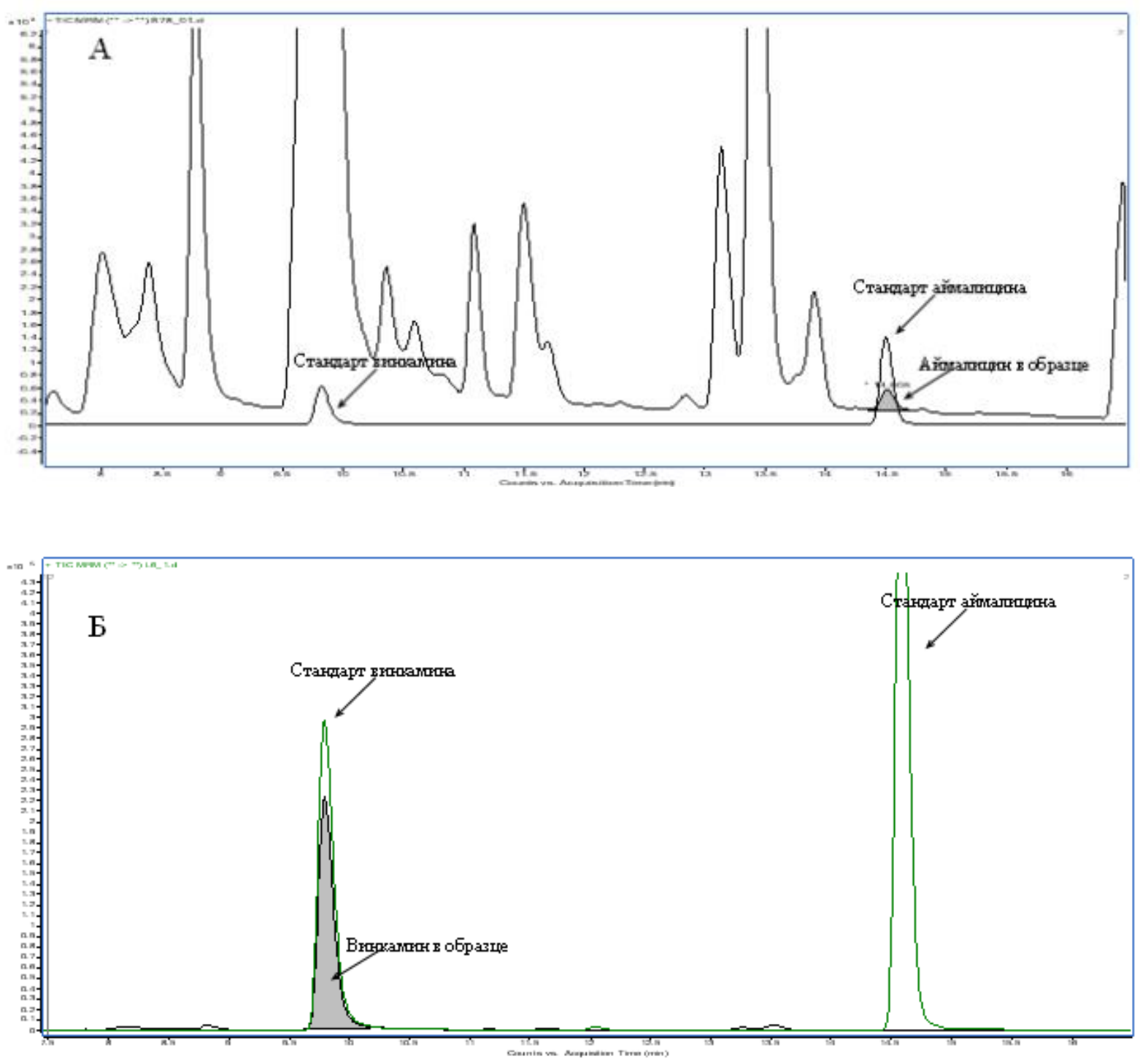

Рис. 1. Хроматограммы экстракта травы $V$. minor L. в сравнении с хроматограммами стандартных образцов: А - содержание аймалицина в образце - 22,2 нг/мл, в стандарте - 100,0 нг/мл; Б - содержание винкамина в образце $-3,7$ мкг/мл, в стандарте -5 мкг/мл
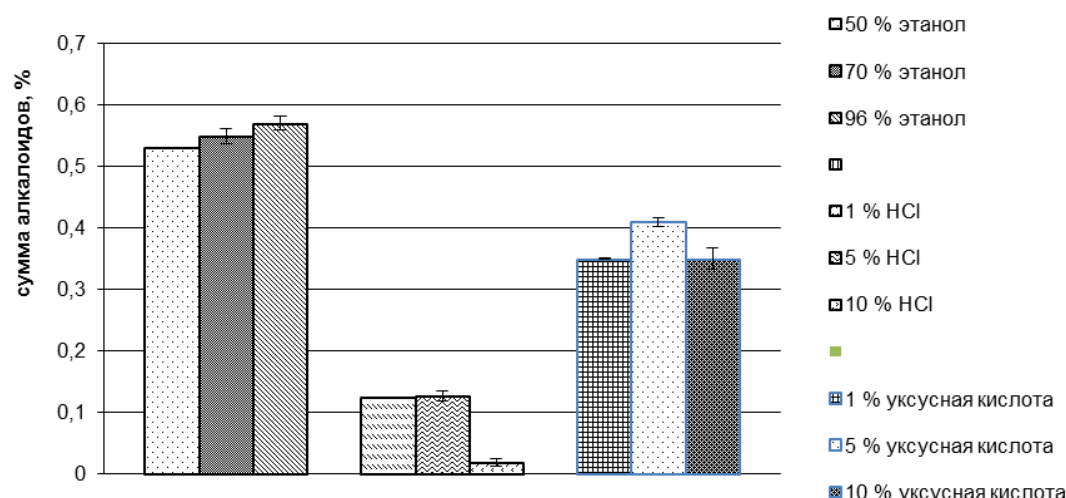

Рис. 2. Выход суммы алкалоидов травы V. minor L. при экстракции водными растворами этанола, соляной и уксусной кислот 
Особый интерес представляет обнаружение в исследуемых экстрактах аймалицина. Как видно из полученных результатов (рис. 3Б), аймалицин был идентифицирован в этанольных (150-170 нг/г) и уксуснокислых экстрактах (150-200 нг/г). Содержание аймалицина в экстрактах при использовании в качестве экстрагента соляной кислоты было ниже предела определения. Таким образом, наибольший выход фармакологически ценных индольных алкалоидов барвинка (винкамина и аймалицина) имеет место при экстракции водными растворами этилового спирта и уксусной кислоты.

Важно было также определить содержание винкамина и аймалицина в различных органах растения. Как видно из данных, представленных в таблице 2, величины содержания винкамина в различных органах барвинка малого сопоставимы с его содержанием по данным [1]. Содержание аймалицина, как уже упоминалось, в барвинке малом ранее не установлено.
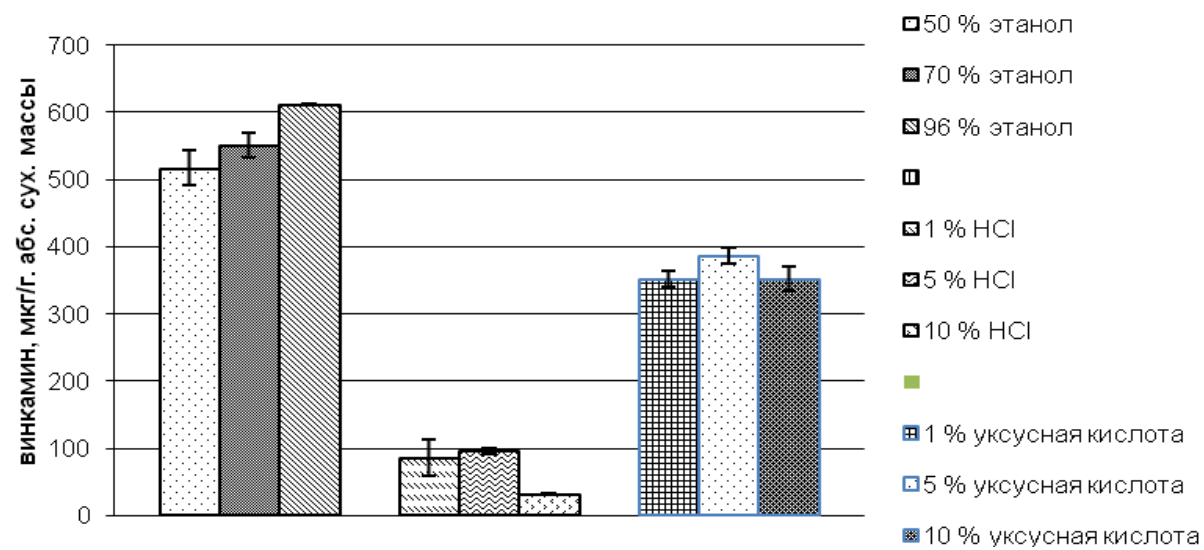

A

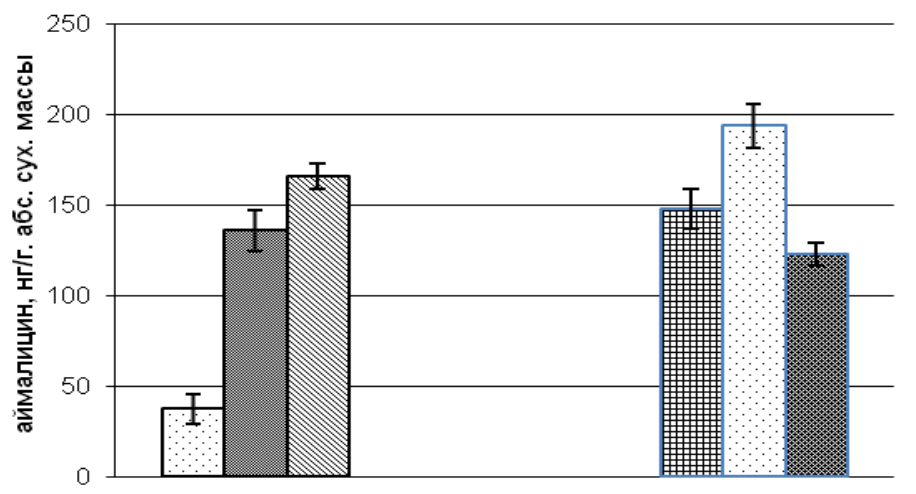

ロ $50 \%$ этанол

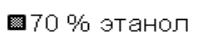

$\mathbf{\$} 96 \%$ этанол

m

ㄴ $1 \% \mathrm{HCl}$

因 $5 \% \mathrm{HCl}$

무 $\mathrm{HCl}$

-1.

円1\% уксусная кислота

๑5 \% уксусная кислота

圈 $10 \%$ уксуснаякислота

Б

Рис. 3. Содержание винкамина (А) и аймалицина (Б) в экстрактах травы V. minor L. при различных способах экстракции

Таблица 2. Содержание винкамина и аймалицина в различных органах Vinca minor L.

\begin{tabular}{l|c|c|c|c}
\hline & \multicolumn{2}{|c|}{ По нашим данным } & \multicolumn{2}{c}{ По литературным данным [1] } \\
\cline { 2 - 5 } & винкамин, мкг/г & аймалицин, нг/г & винкамин, мкг/г & аймалицин, нг/г \\
\hline Корни & $400-500$ & $435-500$ & $650-1050$ & - \\
Листья & $600-700$ & $130-150$ & $300-850$ & - \\
Стебли & $55-60$ & - & $30-45$ & - \\
Цветы & $450-500$ & $150-200$ & $500-700$ & - \\
Трава & $600-980$ & $215-250$ & $450-1050$ & - \\
\hline
\end{tabular}


Таким образом, барвинок малый, культивируемый на территории Беларуси в условиях умеренного континентального климата, может быть использован в качестве сырья для получения фармакологических препаратов. Возможно, что высокое содержание винкамина и биосинтез аймалицина являются следствием адаптивной реакции растения на изменение климатических условий произрастания.

\section{Bblвodbl}

Определено содержание винкамина и аймалицина в различных органах барвинка малого, произрастающего в условиях умеренного континентального климата Беларуси. Установлено, что для эффективной экстракции суммы индольных алкалоидов и винкамина из исследуемого сырья целесообразно использовать водные растворы этилового спирта (не менее 50\%) и уксусной кислоты (не менее 1-5\%). Проведенное исследование свидетельствует о том, что уровень содержания суммы ТИА и винкамина, основного фармакологически ценного компонента барвинка малого, является достаточно высоким и сопоставимым с содержанием ТИА и винкамина в растениях барвинка, произрастающих в более южных регионах. Использование тандемной масс-спектрометрии в MRM-режиме позволило не только точно определить содержание винкамина в экстрактах ТИА, но и идентифицировать аймалицин - алкалоид с крайне низким уровнем содержания. Максимальный выход аймалицина установлен при использовании в качестве экстрагенов 96\% этанола и 5\% уксусной кислоты. Обнаружение фармакологически ценного гипотензивного алкалоида аймалицина в составе ТИА барвинка усиливает коммерческую значимость исследуемого растительного сырья.

\section{Список литературы}

1. Растительные ресурсы СССР: цветковые растения, их химический состав, использование. Л., 1990. Т. 5. 328 с.

2. Победимова Е.Г. и др. Флора СССР. Семейство Аросупасеае / под ред. Б.К. Шишкина, Е.Г. Боброва. М., 1952. C. $646-652$.

3. Регистрация лекарственных средств России / под общ. ред. Г.А. Вышковского. М., 2004. 195 с.

4. Кухарева Л.В., Пашина Г.В. Полезные травянистые растения природной флоры: Справочник по итогам интродукции в Белоруссии. Мн., 1986. 215 с.

5. Джус М.А., Молчан О.В., Кухарева Л.В., Спиридович Е.В., Юрин В.М. Род Vinca L. (Apocynaceae) во флоре Беларуси // Украинский ботанический журнал. 2009. Т. 66, №6. С. 783-793.

6. Verma P., Khan S. A., Mathur A.K., Shanker K., Kalra A. Fungal endophytes enhanced the growth and production kinetics of Vinca minor hairy roots and cell suspensions grown in bioreactor // Plant Cell Tiss. Organ Cult. 2014. Vol. 118. Pp. 257-268.

7. Hirata K., Mukai M., Goda S., Ishio-Kinugasa M., Yoshida K., Sakai A., Miyamoto K. Cryopreservation of hairy root cultures of Vinca minor (L.) by encapsulation-dehydration // Biotechnology Letters. 2002. Vol. 24. Pp. 371-376.

8. Boyadzhiev L. et al. Extraction of vincamine from Periwinkle (Vinca minor L.): obtaining of total extract // Comptes rendus de L'Academie bulgare des Sciences. 2002. Vol. 55 (12). Pp. 49-52.

9. Лешина Л.Г., Булко О.В. Agrobacterium rhisogenes-опосредованная трансформация и регенерация двух видов растений из семейства Аросуnасеае // Физиология и биохимия культурных растений. 2011. Т. 43, №6. С. 533539.

10. Proksa B. et al. High performance liquid chromatographic determination of alkaloids from Vinca minor // Phytochemical Analisis. 1991. Vol. 2. Pp. 74-76.

11. Loyola-Vargas V.M. et al. Catharanthus biosynthetic enzymes: the road ahead // Phytochemistry Reviews. 2007. Vol. 6. Pp. 307-339.

12. Погоцкая А.А., Бузук Г.Н. Сравнительная характеристика влияния различных концентраций хлористоводородной и уксусной кислот на извлечение алкалоидов из листьев маклейи сердцевидной // Вестник фармации. 2010. Т. 48, №2. С. 39-48. 
Molchan O.V.*I, Fatykhava S.A. ${ }^{2}$, Shabunya P.S. ${ }^{2}$, Yurin V.M. ${ }^{3}$ DETERMINATION OF VINCAMINE AND AJMALICINE CONTENTS IN INTRODUCED IN BELARUS VINCA MINOR PLANTS BY HPLC-MS

${ }^{l}$ Institute of Experimental Botany. VF Kuprevich National Academy of Sciences, ul. Academicheskaya, 27, Minsk, 200072 (Republic of Belarus) e-mail: olga_molchan@mail.ru;

${ }^{2}$ Institute of Bioorganic Chemistry of the National Academy of Sciences of Belarus, ul. Kuprevicha, 2, Minsk 220041 (Republic of Belarus)

${ }^{3}$ Belorussky State University, pr. Nezavisimosti 4, Minsk 200030 (Republic of Belarus)

Vincamine and ajmalicine contents was determined by HPLC-MS in common periwinkle plants (Vinca minor L., Apocynaceae) cultivated in moderate continental climate conditions of Belarus. According to our experimental data, levels of terpenoid indole alkaloids (TIA) and vincamine in periwinkle leaves and herbal were comparable to TIA and vincamine concentrations in south plants. The pharmacologically valuable hypotensive alkaloid ajmalicine was identified in V. minor plants. Distributions of vincamine and ajmalicine were studied in different organs of periwinkle plants during the flowering period. It was found that aqueous solutions of ethyl alcohol (not less than 50\%) and acetic acid (1-5\%) are effective to extract indole alkaloid from the herbal materials. It was determined maximum yield of vincamine and ajmalicine in $96 \%$ ethanol and $5 \%$ acetic acid extracts.

Keywords: common periwinkle (Vinca minor L.), terpenoid indole alkaloids (TIA), vincamine, ajmalicine.

\section{References}

1. Rastitel'nye resursy SSSR: cvetkovye rastenija, ih himicheskij sostav, ispol'zovanie. [Plant resources of the USSR: Flowering plants, their chemical composition, the use of]. Leningrad, 1990, vol. 5, 328 p. (in Russ.).

2. Pobedimova E.G. i dr. Flora SSSR. Semejstvo Apocynaceae [Flora of the USSR. The family Apocynaceae], ed. B.K. Shishkin, E.G. Bobrov. Moscow, 1952. pp. 646-652. (in Russ.)

3. Registracija lekarstvennyh sredstv Rossii [Registration of drugs Russia], ed. G.A. Vyshkovskii. Moscow, 2004, 195 p. (in Russ.)

4. Kuhareva L.V., Pashina G.V. Poleznye travjanistye rastenija prirodnoj flory: Spravochnik po itogam introdukcii v Belorussii. [Useful herbaceous plants of the natural flora: A Guide to the results of the introduction in Belarus]. Minsk, 1986, 215 p. (in Russ.)

5. Dzhus M.A., Molchan O.V., Kuhareva L.V., Spiridovich E.V., Jurin V.M. Ukrainskij botanicheskij zhurnal, 2009, vol. 66, no. 6, pp. 783-793. (in Russ.)

6. Verma P., Khan S. A., Mathur A.K., Shanker K., Kalra A. Plant Cell Tiss. Organ Cult. 2014, vol. 118, pp. $257-268$.

7. Hirata K., Mukai M., Goda S., Ishio-Kinugasa M., Yoshida K., Sakai A., Miyamoto K. Biotechnology Letters. 2002, vol. 24, pp. 371-376.

8. Boyadzhiev L. et al. Comptes rendus de L'Academie bulgare des Sciences. 2002, vol. 55 (12), pp. 49-52.

9. Leshina L.G., Bulko O.V. Fiziologija i biohimija kul'turnyh rastenij. 2011, vol. 43, no. 6, pp. 533-539. (in Russ.)

10. Proksa B. et al. Phytochemical Analisis. 1991, vol. 2, pp. 74-76.

11. Loyola-Vargas V.M. et al. Phytochemistry Reviews. 2007, vol. 6, pp. 307-339.

12. Pogockaja A.A., Buzuk G.N. Vestnik farmacii. 2010, vol. 48, no. 2, pp. 39-48. (in Russ.)

Received May 27, 2015

Revised June 15, 2015

\footnotetext{
"Corresponding author.
} 
